\title{
The Role of Nitrergic System in Lidocaine-Induced Convulsion in the Mouse
}

\author{
Mehmet Kurt*, S. Sirri Bilge, Osman Kukula, Yuksel Kesim and Suleyman Celik \\ Department of Pharmacology, Faculty of Medicine, Ondokuz Mayis University, Samsun, Turkey 55139
}

Received August 22, 2000 Accepted October 31, 2000

\begin{abstract}
The effects of $N$-nitro-L-arginine-methyl ester (L-NAME) a nitric oxide (NO) synthase inhibitor and L-arginine, a NO precursor, were investigated on lidocaine-induced convulsions. In the first experiment, four groups of mice received physiological saline $(0.9 \%)$, L-arginine $(300 \mathrm{mg} / \mathrm{kg}$, i.p.), L-NAME $(100 \mathrm{mg} / \mathrm{kg}$, i.p.) and diazepam $(2 \mathrm{mg} / \mathrm{kg})$, respectively. Thirty minutes after these injections, all mice received lidocaine $(50 \mathrm{mg} / \mathrm{kg}$, i.p.). In the second experiment, four groups of mice received similar treatment in the first experiment, and $30 \mathrm{~min}$ after these injections, all mice received a higher dose of lidocaine $(80 \mathrm{mg} / \mathrm{kg})$. L-NAME $(100 \mathrm{mg} / \mathrm{kg}$, i.p. $)$ and diazepam $(2 \mathrm{mg} / \mathrm{kg})$ significantly decreased the incidence of lidocaine $(50 \mathrm{mg} / \mathrm{kg})$-induced convulsions. In contrast, the L-arginine treatment increased the incidence of lidocaine $(80 \mathrm{mg} / \mathrm{kg}$, i.p.)-induced convulsions significantly. These results may suggest that NO is a proconvulsant mediator in lidocaine-induced convulsions.
\end{abstract}

Keywords: Lidocaine, Convulsions, $N$-nitro-L-arginine-methyl ester, L-arginine

The neuropharmacologic signs of toxicity from local anesthetics are excitation of the central nervous system (CNS) and generalized tonic clonic convulsions. Several neuromediators and mechanisms may be involved in lidocaineinduced convulsions. It is generally agreed that local anesthetics may induce convulsions by depressing inhibitory neurons, thereby allowing facilitiation of excitatory neuronal activity $(1-3)$. Nitric oxide (NO), a putative neurotransmitter in the CNS, enhances neurotransmitter release and has been implicated in the regulation at synaptic functions (4). Although much experimental evidence has indicated that brain NO plays a role in various models of convulsions, the role of NO in such convulsions is still unclear and has not been investigated widely. The aim of this study was to investigate the effects of NO on lidocaine-induced convulsions.

\section{MATERIAL AND METHODS}

\section{Animals}

Male Albino mice weighing $25-40 \mathrm{~g}(\mathrm{n}=242)$ were used in all experiments. Animals were housed in groups of eight in a temperature controlled room $\left(20 \pm 2^{\circ} \mathrm{C}\right)$ with a 12-h light 12-h dark cycle (lights on at 07.00 a.m.). The

*Corresponding author. FAX: +90-362-4576041

E-mail: mehmet.kurt@turkport.com animals had a period of adaptation for three days and allowed free access to food and water prior to the experiments. All experiments were performed in the afternoon because of the possible effects of circadian rhythms on experiments. Each animal was used once. All experiments were carried out according to the guidelines of the European Community Council for experimental animal care.

\section{Data analyses}

The incidance of convulsions were obtained from the appearance of clonic convulsions for each group. The statistical analysis of significance of the difference in incidence of convulsions was made by the chi square test.

\section{Drugs}

$N$-nitro-L-argininne-methy ester (L-NAME, Sigma), L-arginine (Sigma) and lidocaine (Sigma) were dissolved in physiological saline $(0.9 \%)$. The commercial preparation of diazepam was diluted in 5\% propylene glycol aqueous solution. In the first experiments, three groups of mice received physiological saline $(0.9 \%)$, L-arginine $(300 \mathrm{mg}$ $/ \mathrm{kg})$, L-NAME $(100 \mathrm{mg} / \mathrm{kg})$ and diazepam $(2 \mathrm{mg} / \mathrm{kg})$, respectively. Thirty minutes after these injections, all mice received lidocaine $(50 \mathrm{mg} / \mathrm{kg})$. In the second set of experiments, the remaining groups of mice received similar treatment as in the first experiment, and $30 \mathrm{~min}$ after the injections, all mice received lidocaine $(80 \mathrm{mg} / \mathrm{kg})$. All drugs 
were administered intraperitoneally at doses of $0.01 \mathrm{ml}$ $/ 10 \mathrm{~g}$ body weight and equivalent volumes of vehicle were injected in control groups. Groups of 22 to 36 mice were used for each treatment. L-NAME, L-arginine or vehicle were administered at $30 \mathrm{~min}$ before the lidocaine treatment.

\section{RESULTS}

Lidocaine produced ataxia, loss of righting reflex and clonic convulsions $5 \mathrm{~min}$ after the injection. The effects of L-arginine $(300 \mathrm{mg} / \mathrm{kg})$, L-NAME (100 mg/kg, i.p.) and diazepam $(2 \mathrm{mg} / \mathrm{kg}$, i.p.) on the incidence of lidocaine-induced convulsions are shown in Table 1. In the L-NAMEtreated mice, the incidence of lidocaine $(50 \mathrm{mg} / \mathrm{kg}$, i.p.)induced convulsions were decreased. Conversely the incidence of lidocaine $(80 \mathrm{mg} / \mathrm{kg}$, i.p.)-induced convulsion were increased significantly by L-arginine treatment.

\section{DISCUSSION}

There are some contradictory reports about the role of the nitrergic system in convulsions. Marangoz and Agar (5) have suggested that NO may be an endogenous anticonvulsant substance in the penicillin model of experimental epilepsy. In the same way, Jayakumar et al. (6) have found that L-arginine, a precursor of NO, inhibited picrotoxin-induced convulsions, suggesting that NO may play a role as an endogenous anticonvulsant substance. In contrast to these reports, Mülsch et al. (7) demonstrated an increase in NO formation in kainate-treated mice, but a reduction in both NO production and kainate-induced convulsions in mice pretreated with nitric oxide synthase (NOS) inhibitor. They suggested that NO has a proconvulsant role in kainateinduced convulsions. Kýrkby et al. (8) have suggested that NO may be an endogeneous anticonvulsant in kainateinduced convulsions.

Contradictory results about the role of NO in convulsions may be explained by the different experimental convulsion models and convulsant agents.

Del-Bel et al. (9) have examined the role of NO in convulsion using different agents and models and suggested that the effects of NOS inhibitors vary depending on the seizure model. For this reason, we investigated the function of NO using a different model in this study. In the present study, the incidence of lidocaine-induced convulsions in mice decreased significantly when L-NAME was administered prior to lidocaine, whereas L-arginine increased the convulsions induced by lidocaine. Glutamate is an excitatory neurotransmitter in the brain. It also plays a critical role in epileptogenesis. Glutamate antagonists are potent anticonvulsants in a wide variety of animal models (1012).

There are some evidence that local anesthetics may induce convulsions by activating glutamatergic receptors $(10-13)$. Both $N$-methyl-D-aspartic acid (NMDA) and non-NMDA receptor systems have been shown to be involved in local anesthetic-induced convulsions (13). It has been reported that CGS 19755, a competetive NMDA-receptor antagonist, increased the lidocaine-induced seizure threshold (11). In the CNS, NO is considered as a retrograde messenger involved in glutamatergic neurotransmission (14). NO is produced by NOS from L-arginine and NOS is activated by glutamate via NMDA receptor (15). Mülsch et al. (7) have reported that the epileptogenic activity of kainate, a glutamatergic agonist, is likely to be based on a NO response in the amygdale/temporal cortex. Acute increase in NO formation may also be responsible for other neuroexcitator-induced seizures.

Recent reports indicate that NOS inhibitors have both anticonvulsant (16-19) and proconvulsant actions (6, $20-$ 22). NOS inhibitors have been reported to exert an anticonvulsant effect on NMDA and kainate-induced convulsions (7). In the present study, L-NAME, a NOS inhibitor, significantly reduced lidocaine-induced convulsions. In the

Table 1. The effects of L-arginine, L-NAME and diazepam on the incidence of lidocaine-induced convulsions in mouse

\begin{tabular}{lccccc}
\hline Drugs & $\begin{array}{c}\text { Dose } \\
\mathrm{mg} / \mathrm{kg}\end{array}$ & $\begin{array}{c}\text { Lidocaine } \\
\mathrm{mg} / \mathrm{kg}\end{array}$ & $\mathrm{n}$ & $\begin{array}{c}\text { Numbers of animals } \\
\text { with convulsions }\end{array}$ & $\begin{array}{c}\% \text { of animals with } \\
\text { convulsions }\end{array}$ \\
\hline Control & 0 & 50 & 22 & 10 & 45 \\
L-Arginine & 0 & 80 & 32 & 27 & 86 \\
& 300 & 50 & 36 & 14 & 41 \\
L-NAME & 300 & 80 & 32 & 32 & $100^{*}$ \\
& 100 & 50 & 28 & 3 & $11^{*}$ \\
Diazepam & 100 & 80 & 30 & 18 & 60 \\
& 2 & 50 & 32 & 2 & $6^{*}$ \\
\hline
\end{tabular}

$* P<0.05$, significantly different from control. 
light of the data presented in this study, it is possible to suggest that the modulation of glutamatergic activity by lidocaine may result in enhanced NO signaling. Thus, NO may affect lidocaine-induced convulsion by altering glutamatergic activity (23). According to the results that Larginine was uneffective on convulsions induced by low doses of lidocaine and that L-NAME was uneffective on convulsions caused by high doses of lidocaine suggest that the glutamergic system may not be sufficiently modulated in these groups.

We have demonstrated that the nitrergic system may have an excitatory effect on lidocaine-induced convulsions, and NO may play an important role as an endogenous convulsant substance in mice.

\section{REFERENCES}

1 Abed WT: Alterations of lidocaine and penylenetetrazol-induced convulsions by manuplation of brain monoamines. Pharmacol Toxicol 75, 162 - 165 (1994)

2 Yoshimura Y, Dohi T, Tanaka S, Takada K and Tsujimoto A: Changes in convulsion susceptibility of lidocaine by alteration of brain catecholaminergic functions. Jpn J Pharmacol 56, 85 - 91 (1991)

3 Endo K, Morita K, Uchiyama Y and Takada K: Involvement of brain serotonergic function in lidocaine-induced convulsions in mice. Jpn J Pharmacol 62, 325 - 328 (1993)

4 Murayama T and Nomura Y: The actions of NO in the central nervous system and thymocytes. Jpn J Pharmacol 76, 129 - 139 (1998)

5 Marangoz C and Agar E: Evidence that sodium nitroprusside possesses anticonvulsant effects mediated through nitric oxide. Neuroreport 5, 2454 - 2456 (1994)

6 Jayakumar AR, Sujatha R and Paul V: Involvement of nitric oxide and nitric oxide synthase activity in anticonvulsive action. Brain Res Bull 48, 387 - 394 (1999)

7 Mülsch A, Busse R, Mordvintcev P and Vanin AF: Nitric oxide promotes seizure activity in kainate-treated rats. Neuroreport $\mathbf{5}$, $2325-2328$ (1994)

8 Kýrkby RD, Forbes RA and Subramaniam S: Modification of kainate-induced behavioral and electrographic seizures following inhibition of nitric oxide synthase in mice. Epilepsy Res 24, $79-90$ (1996)

9 Del-Bel EA, Oliveira PR, Oliveria JA and Mishra PK: Anticonvulsant and proconvulsant roles of nitric oxide in experimental epilepsy models. Braz J Med Biol Res 30, 971 - 979 (1997)

$10 \mathrm{Chen} \mathrm{CH}$, Chen $\mathrm{AC}$ and Liu HJ: Involvement of nitric oxide and
$\mathrm{N}$-methyl-D-aspartate in acute hypoxic altitude convulsion in mice. Aviat Space Environ Med 68, 296 - 299 (1997)

11 McFarlane C, Warner D and Dexter F: Glutamergic antagonism: effects on lidocaine-induced seizures in the rat. Anesth Analg 79, $701-705$ (1994)

12 Hwa GGC and Avoli M: The involvement of excitatory amino acids in neocortical epileptogenezis: NMDA and non-NMDA receptors. Exp Brain Res 86, 248 - 256 (1991)

13 Barat SA and Abdel-Rahman MS: Decreased cocaine- and lidocaine-induced seizure response by dextromethorphan and DNQX in rat. Brain Res 9, 179 - 183 (1997)

14 Kennedy MB: The biochemistry of synaptic regulation in the central nervous system. Annu Rev Biochem 63, 571-600 (1994)

15 Desvignes C, Robert F, Vachette C and Chouvet G: Monitoring nitric oxide (NO) in rat locus coeruleus. Differential effects of NO synthase inhibitors. Neuroreport 8, 1321 - 1325 (1997)

16 Masukawa T, Nakanishi K and Natsuki R: Role of nitric oxide in the convulsions following the coadministration of enoxacin with fenbufen in mice. Jpn J Pharmacol 76, 425 - 429 (1998)

17 Kohno K, Niwa M, Nozaki M, Uematsu T and Fujimura H: Role of nitric oxide in the convulsive seizures induced by fluoroquinolones coadministered with 4-biphenyl acetic acid. Gen Pharmacol 29, 767 - 770 (1997)

18 Takei Y, Takashima S, Ohyu J, Takami T, Miyajima J and Hoshika A: Effects of nitric oxide synthase inhibition on the cerebral circulation and brain damage during kainic acidinduced seizures in newborn rabbits. Brain Dev 21, $253-259$ (1999)

19 Marks KA, Mallard CE, Roberts I, Williams CE and Gluckman PD: Nitric oxide synthase inhibition and delayed cerebral injury after severe cerebral ischemia in fetal sheep. Pediatr Res 46, 8 13 (1999)

20 Tsuda M and Suzuki T: Aggravation of DMCM-induced seizure by nitric oxide synthase inhibitors in mice. Life Sci $\mathbf{6 0}, 339-$ 343 (1997)

21 Borowicz KK, Starownik R, Kleinrok Z and Czuczwar SJ: The influence of $\mathrm{L}-N^{\mathrm{G}}$-nitroarginine methyl ester, an inhibitor of nitric oxide synthase, upon the anticonvulsive activity of conventional antiepileptic drugs against maximal electroshock in mice. J Neural Transm 105, 1 - 12 (1998)

22 Czuczwar SJ, Tutka P, Klonowski P and Kleinrok Z: $N^{\mathrm{G}}$-NitroL-arginine impairs the anticonvulsive action of ethosuximide against pentylentetrazol. Eur J Pharmacol 366, 137 - 142 (1999)

23 Rundfeldt C, Koch R, Richter A, Mevissen M and Gerecke U: Dose dependent anticonvulsant and proconvulsant effects of nitric oxide synthase inhibitors on seizure threshold in a cortical stimulation model in rats. Eur J Pharmacol 274, 73 - 81 (1995) 